\title{
RENDAHNYA KADAR VITAMIN D BERPENGARUH PADA JUMLAH TH 17 PASIEN LUPUS ERITEMATOSUS SISTEMIK
}

\author{
Wira Daramatasia \\ wira.daramatasia@gmail.com
}

\section{STIKES Widyagama Husada}

\begin{abstract}
Systemic Lupus Erythematosus (SLE) is an autoimmune disease that is more frequently found with a high mortality rate. Aetiopathogenesis of the disease is unclear, although it has been demonstrated abnormalities of various immune cells including $T$ cell hyperreactivity, B cells, dendritic cells, and decreased function of regulatory $T$ cells (Treg). Vitamin $D$ has a role in the immune system regulation, but in patients with SLE is still a lot of controversy. This study aims at funding out the correlation of vitamin D level with the percentage amount of Th17 cells in patients with SLE.

Observation Laboratory in the form of a cross -sectional study with blood sampling SLE patients and healthy control in RSSA. Of the total 48 SLE patients and 23 healthy controls, this study compared the amount (percentage) of Th17 cells by looking at level of vitamin D. SLE patient's vitamin D level was measured by ELISA method, the amount of the percentage of Th17 cells $\left(C D 4^{+}, I L 17^{+}\right)$was measured by using a BD FACSCalibur flowcytometri method.

The mean levels of vitamin D of SLE patients compared to healthy controls differed significantly ( $p=$ 0.00). There are significant differences in the number of Th17 percentage $(p=0.04)$, and Tukey test results between the control group of SLE patients with hypovitamin $D(p=0.03)$. There is no correlation between vitamin $D$ status with Th 17 cells $(P=0.22$ and $r=-0,33)$. Conclusion, It is concluded that $1,25(\mathrm{OH}) 2 \mathrm{D} 3$ affects the cell life cycle stages. This effect could contribute substantially to reduce the activation of $T$ cells in inducing $T h$ cell development 17 . therefore by providing therapy vitamin $D$ (analog 1,25 (OH) 2D3) can modulate the treatment of autoimmune diseases, particularly SLE patient.
\end{abstract} Keywords: SLE, Vitamins D, Th17 


\begin{abstract}
ABSTRAK
Lupus Eritematosus Sistemik (LES) merupakan penyakit autoimun yang semakin sering dijumpai dengan angka kematian tinggi. Etiopatogenesis penyakit ini belum jelas, meskipun telah ditunjukkan adanya abnormalitas berbagai sel-sel imun termasuk hiperreaktivitas sel $T$, sel B, sel dendrit, dan menurunnya fungsi sel $T$ regulator (Treg). Vitamin $D$ memiliki peran dalam pengaturan sistem imun, namun pada pasien LES masih banyak kontroversi. Penelitian ini bertujuan untuk mengetahui hubungan kadar vitamin D dengan jumlah prosentase sel Th17 pada pasien LES.

Observasi laboratorium dalam bentuk cross sectional study dengan pengambilan sampel darah pasien LES dan kontrol sehat di RSSA. Dari jumlah 48 pasien LES dan 23 kontrol sehat, Penelitian ini membandingkan jumlah (prosentase) sel Th17 dengan melihat kadar vitamin D. Kadar vitamin D pasien LES diukur dengan metoda ELISA, jumlah prosentase sel Th17 $\left(\mathrm{CD}^{+}, \mathrm{IL17}^{+}\right)$diukur dengan metoda flowcytometri menggunakan BD FACScalibur..

Rerata kadar vitamin D pasien LES berbeda signifikan dibandingkan kontrol sehat $(p=0.00)$. Terdapat perbedaan signifikan dengan jumlah prosentase Th17 $(p=0,04)$, dan hasil uji Tukey antara kelompok kontrol dengan pasien LES hipovitamin $D(p=0,03)$. Tidak ada hubungan antara status vitamin $D$ dengan sel Th $17(P=0,22, r=-0,33)$.

Dapat disimpulkan bahwa 1,25(OH)2D3 mempengaruhi tahapan siklus hidup sel. Efek ini dapat berkontribusi secara substansial untuk mengurangi aktivasi sel $T$ dalam menginduksi perkembangan sel Th 17. Oleh Karenanya mungkin pemberian terapi vitamin D (analog 1,25(OH)2D3) dapat memodulasi dalam pengobatan penyakit autoimun, khususnya pasien LES.
\end{abstract}

Kata kunci: LES, Vitamin D, Th17

\section{PENDAHULUAN}

Lupus Eritematosus Sistemik (LES) merupakan suatu penyakit autoimun sistemik yang akhir-akhir ini semakin sering dijumpai. Penyakit ini terutama menyerang wanita usia reproduktif dengan perbandingan wanita:laki berkisar 8:1. Prevalensi LES dilaporkan berkisar 12,2 per 100.000 penduduk dengan angka mortalitas dan morbiditas yang cukup tinggi terutama di negara-negara berkembang (Shakra, 2008). Patogenesis LES hingga saat ini belum dapat diketahui dengan jelas. Adanya sel-sel sistem imun yang hiperreaktif dan diproduksinya autoantibodi patogenik yang pada akhirnya menyebabkan terjadinya keradangan sistemik dan kerusakan jaringan telah lama diketahui. Berbagai abnormalitas sel T, sel B, sel plasma, sel dendritik serta sel $\mathrm{T}$ regulator telah dilaporkan dalam berbagai penelitian (Anolik , 2007 ; Jianxin, 2009). Di samping itu sitokin diduga juga ikut berperan dalam patogenesis lupus. Keseimbangan sitokin Th1/Th2 serta Th17 telah ditunjukkan berkaitan dengan berbagai manifestasi klinis lupus (Sayed, 2008). Meskipun secara umum angka harapan hidup 10 tahun penderita LES meningkat hingga mencapai $90 \%$ pada tahun 2000 di negara maju, penelitian Kalim (2000) menunjukkan bahwa penderita LES di Indonesia mempunyai harapan hidup yang masih rendah, yakni untuk 5 tahun $70 \%$ dan untuk 10 tahun 55\% (Kalim., 2000).

Akhir-akhir ini telah dilaporkan adanya hubungan antara rendahnya kadar vitamin D dengan timbulnya penyakit autoimun termasuk LES (Irastorza et al., 2008). Terdapat korelasi negatif kadar vitamin $\mathrm{D}$ dengan aktivitas penyakit dan produksi autoantibodi serta peningkatan fungsi sel dendritik (Adams and Hewison, 2008).Vitamin D dilaporkan memiliki efek menghambat diferensiasi sel monosit menjadi sel dendritik (Cutolo, 2009), kemudian mempertahankan sel dendritik dalam kondisi imatur (Dusso et al., 2005). Lebih lanjut dilaporkan bahwa vitamin D menghambat aktivasi sel $\mathrm{T}$ yang tergantung sel dendritik 
(Cutolo, 2009), menurunkan sekresi sitokin Th1 dan Th2 serta menginduksi perkembangan sel $\mathrm{T}$ regulator (Ghoreishi et al., 2009). Berbagai penelitian lain telah melaporkan bahwa rendahnya kadar vitamin D pada pasien LES berkaitan dengan peningkatan proliferasi sel $\mathrm{B}$, polimorfisme reseptor vitamin $\mathrm{D}$ (VDR) yang berada pada permukaan sel (Toubi and Shoenfeld, 2010).

Kurangnya paparan sinar matahari merupakan penyebab utama defisiensi vitamin D pada ras Kaukasia, karena sekitar $80 \%$ vitamin D dalam tubuh berasal dari previtamin D yang diproduksi di kulit yang diinduksi oleh sinar ultra violet B (Szodaray et al., 2008). Sedangkan negara Indonesia terletak di katulistiwa dengan paparan sinar matahari sepanjang tahun. Sehingga timbul pertanyaan apakah beratnya manifestasi klinis pasien-pasien LES di Indonesia juga dipengaruhi kadar vitamin D. Studi-studi klinis juga belum lengkap dalam mengevaluasi efek vitamin $\mathrm{D}$ terhadap aktivitas LES .

Bagaimana keterkaitan antara LES sebagai sebuah penyakit autoimun dengan sel Th17 sebagai komponen yang mencegah autoimunitas, vitamin D sebagai modulator sistem imun belum jelas, sehingga ingin diungkap pada penelitian ini.

\section{METODE PENELITIAN}

Rancangan dalam penelitian ini adalah observasi dalam bentuk cross sectional study dengan pengambilan sampel darah untuk mengetahui kadar vitamin D serum, prosentase IL-17 pada pasien-pasien LES dibandingkan dengan kontrol sehat. Lama penelitian selama 11 bulan dan sudah memenuhi kelayakan etik penelitian dari Fakultas Kedokteran Universitas Brawijaya, Malang.

Populasi penelitian adalah pasien LES dan sampel adalah pasien LES yang memenuhi kriteria inklusi subjek sakit (didiagnosis LES oleh dokter ilmu penyakit dalam konnsultan rheumatology berdasarkan kriteria ARA, penyakit dalam keadaan aktif berdasarkan skor SLEDAI serta tidak mengkomsumsi vitamin D), dan kontrol sehat adalah orang yang memenuhi kriteria inklusi subjek kontrol (usia, jenis, kelamin dan suku bangsa yang sesuai dengan subjek sakit, dinyatakan sehat berdasarkan pemeriksaan fisik, pemeriksaan laboratorium, dan pemeriksaan penunjang oleh dokter ahli penyakit dalam, serta tidak mengkomsumsi vitamin D)

Lokasi penelitian di Laboratorium Biomedik Fakultas Kedokteran Universitas Brawijaya Malang dan Laboratorium Sentral RS. Dr. Saiful Anwar Malang.

Kadar vitamin D yang diukur adalah kadar 25(OH)D3 dalam serum diukur dengan metoda Enzyme-Linked Immunosorbent Assay menggunakan kit ELISA dari Cusabio. Nilai normal adalah $\geq 30 \mathrm{ng} / \mathrm{ml}$, Hipovitamin $\mathrm{D} \leq$ adalah $29,9 \mathrm{ng} / \mathrm{ml}$.

Jumlah sel Th 17 adalah jumlah sel limfosit $\mathrm{T}$ yang mengekspresikan CD4+IL17+ yang diukur dengan metode flowcytometry menggunakan BD FACScalibur. Kultur sel limfosit dari PBMC (peripheral blood mononuclear cells ) selama 3 hari, Label CD4 menggunakan FITC dan IL-17 menggunakan PerCP/Cy5,5

Data yang telah terkumpul dianalisa dengan bantuan program SPSS versi 16. Perbedaan status vitamin D antara kelompok pasien LES dengan kontrol dianalisis dengan uji-T tidak berpasangan, jumlah prosentase sel Th 17 pada pasien LES normovitamin D, hipovitamin D, dan kontrol sehat dianalisis dengan uji Anova. Pengaruh status vitamin D dengan Th17 diuji korelasi Pearson. Signifikansi statistik ditentukan jika nilai $\mathrm{p} \leq$ 0.05 .

HASIL

Karakteristik Pasien LES dan Kontrol Sehat Penelitian yang telah dilakukan selama 11 bulan melibatkan 48 pasien LES 
dan 23 kontrol sehat. Tabel 1 menunjukkan karakteristik pasien LES (45 wanita, 3 pria, usia berkisar antara 12 hingga 51 tahun dengan rerata umur $29.35 \pm 9.99$ tahun) dan kontrol sehat (23 wanita, usia berkisar antara 22 hingga 47 tahun dengan rerata umur $32.91 \pm 5.92$ tahun). Satu pasien LES (2\%) memiliki skor SLEDAI $<3$ dan sisanya, 47 pasien LES (98\%) memiliki skor SLEDAI $>3$. Gejala klinis terbanyak yang dialami oleh pasien LES adalah nefritis (50\%), diikuti rash, borok oral, radang sendi, serositis, gangguan neurologik, gangguan hematologik. Berdasarkan pemeriksaan laboratorium, semua pasien LES memiliki kadar komplemen yang rendah.

Tabel 1. Karakteristik Pasien LES dan Kontrol Sehat

\begin{tabular}{lcc}
\hline \multicolumn{1}{c}{ KARAKTERISTIK } & PASIEN LES & KONTROL SEHAT \\
\hline Jenis kelamin $(\mathrm{P} / \mathrm{W})$ & $3 / 45$ & $0 / 23$ \\
Usia (tahun) & $29.35 \pm 9.99$ & $32.91 \pm 5.92$ \\
SLEDAI : & & \\
$\quad$ SLEDAI 0 & 0 & \\
SLEDAI 1-3 & $2 \%$ & \\
SLEDAI $>3$ & $98 \%$ & \\
Kelainan Klinis : & & \\
Nefritis & $50 \%$ & \\
Rash & $46 \%$ & \\
Borok oral & $40 \%$ & \\
Radang sendi & $27 \%$ & \\
Serositis & $19 \%$ & \\
Gangguan & $10 \%$ & \\
neurologik & $6 \%$ & \\
Gangguan & & \\
hematologic & $35.15 \pm 7.61 \mathrm{ng} / \mathrm{mL}$ & \\
Vitamin D & & \\
\hline
\end{tabular}

Keterangan $\mathrm{P}=$ Pria, $\mathrm{W}=$ Wanita

Kadar Vitamin D antara Kelompok Pasien LES dan Kontrol Sehat

Pada semua pasien LES (48 pasien) dan kontrol sehat (23 orang) dilakukan pemeriksaan kadar vitamin $\mathrm{D}$ serum yaitu kadar 25(OH)D3, dengan menggunakan metode ELISA. Hasil pemeriksaan menunjukkan rerata kadar vitamin $\mathrm{D}$ pasien LES $18.68 \pm 11.66 \mathrm{ng} / \mathrm{mL}$, dengan kadar vitamin D terendah, $2.1 \mathrm{ng} / \mathrm{mL}$ dan tertinggi, $50.4 \mathrm{ng} / \mathrm{mL}$. Dua puluh sembilan pasien LES $(60 \%)$ mengalami defisiensi vitamin $\mathrm{D}, 12$ pasien LES (25\%) mengalami insufisiensi vitamin D dan sisanya (15\%) mempunyai kadar vitamin D normal. Pada kontrol sehat, rerata kadar vitamin $\mathrm{D}, 35.15 \pm 7.61 \mathrm{ng} / \mathrm{mL}$, dengan kadar vitamin $\mathrm{D}$ terendah $18.9 \mathrm{ng} / \mathrm{mL}$ dan kadar vitamin D tertinggi $48.30 \mathrm{n} / \mathrm{mL}$. Satu kontrol sehat (4\%) mengalami defisiensi vitamin D, 4 kontrol sehat (17\%) mengalami insufisiensi vitamin $\mathrm{D}$ dan 18 kontrol sehat (79\%) memiliki kadar vitamin D normal. Rerata kadar vitamin D antara pasien LES dan kontrol sehat menunjukkan adanya perbedaan yang signifikan ( $p$ value $=0.00)$, kadar vitamin D antara kelompok pasien LES dan kontrol sehat ditunjukan pada Tabel 2 dan Gambar 1. 
Tabel 2. Karakteristik Vitamin D Pada Kelompok Pasien LES dan Kontrol

\begin{tabular}{lccc}
\hline \multicolumn{1}{c}{ Vitamin D } & $\mathbf{N}$ & Mean \pm SD & Subset $\mathbf{P}(\leq \mathbf{0 . 0 5})$ \\
\hline Kontrol Sehat & 23 & $35.15 \pm 7.61 \mathrm{ng} / \mathrm{mL}$ & $\mathrm{A}$ \\
Pasien LES & 48 & $18.68 \pm 11.66 \mathrm{ng} / \mathrm{mL}$ & $\mathrm{B}$ \\
\hline
\end{tabular}

Keterangan : Subset yang berbeda menunjukkan perbedaan yang signifikan $p$-value $=0,00$

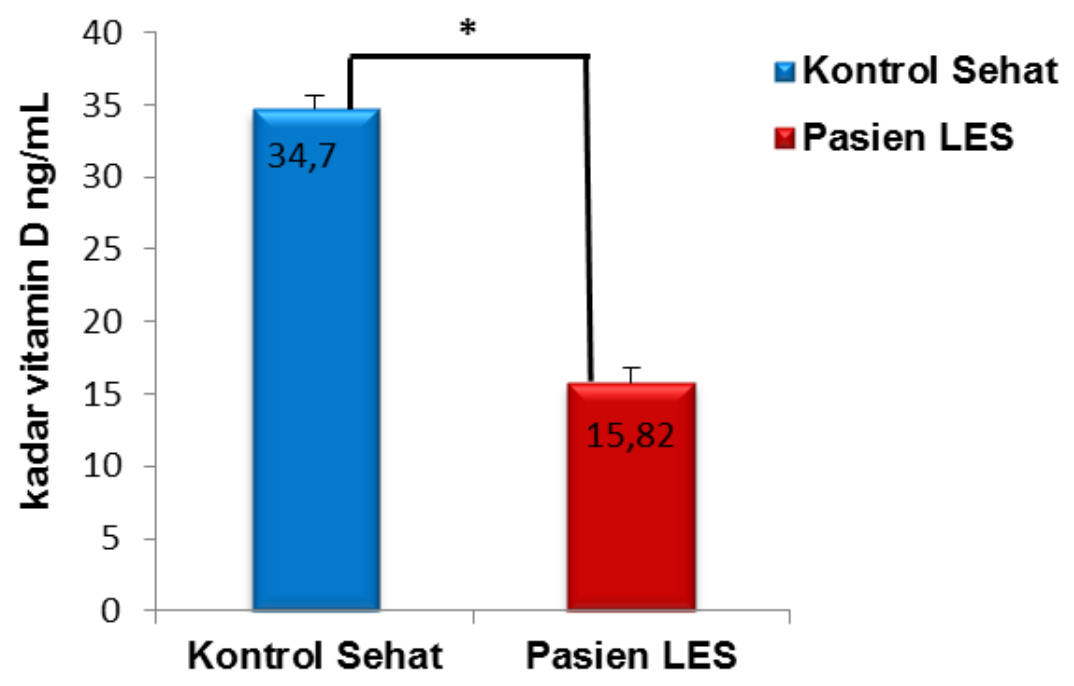

Gambar 1 : Rerata kadar vitamin D pada kontrol sehat dan pasien LES.

Rerata kadar vitamin D dibandingkan antara kontrol sehat $(\mathrm{n}=48)$ dengan pasien LES ( $\mathrm{n}=23)$, Perbedaan yang signifikan ditandai dengan asterisk $\left({ }^{*} \mathrm{p}<0,05\right)$.

Ekspresi Sel Th 17
Hasil pengukuran ekspresi sel Th 17 pada kelompok normovitamin D, hipovitamin D dan kontrol sehat dapat dilihat dari populasi $\mathrm{CD}^{+} \mathrm{CD}^{+} \mathrm{IL} 7^{+}$yang dapat digambarkan pada Tabel 3

Tabel 3: Hasil Kuantifikasi Prosentase Jumlah Th 17 Kelompok Pasien LES dan Kontrol Sehat

\begin{tabular}{llcc}
\hline Vitamin D & N & Mean \pm SD & Subset P $(\leq \mathbf{0 . 0 5})$ \\
\hline Normovitamin D & 5 & $23,93 \pm 24,53$ & AB \\
Hipovitamin D & 5 & $37,59 \pm 34,44$ & B \\
Kontrol & 5 & $4,4 \pm 0,97$ & A \\
\hline
\end{tabular}

Keterangan : * Subset yang berbeda menunjukkan perbedaan yang signifikan

* Subset yang sama menunjukkan tidak ada perbedaan yang nyata, $\mathrm{N}=$ jumlah sampel (ulangan perlakuan)

Dari Tabel 3 dapat diketahui bahwa Jumlah prosentase Th 17 yang lebih tinggi terdapat pada kelompok pasien dengan hipo vitamin D $(37,59 \pm 34,44)$ dan terendah pada kelompok kontrol sehat $(4,4 \pm 0,97)$. Terdapat perbedaan signifikan dengan jumlah prosentase Th $17(\mathrm{p}=0,04)$, dan hasil uji Tukey antara kelompok kontrol dengan pasien 
hipovitamin $\mathrm{D}(\mathrm{p}=0,03)$. Jumlah prosentase Th 17 pada kelompok hipovitamin D lebih banyak sebesar 57\% dari yang kelompok

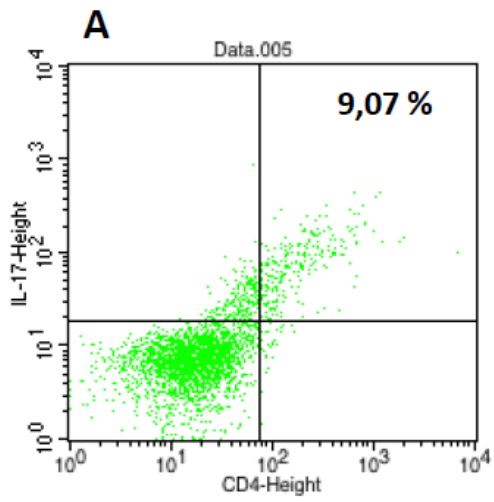

normal pasien LES dan dibandingkan kelompok kontrol lebih banyak sebesar 88,3 $\%$ (Gambar 2)

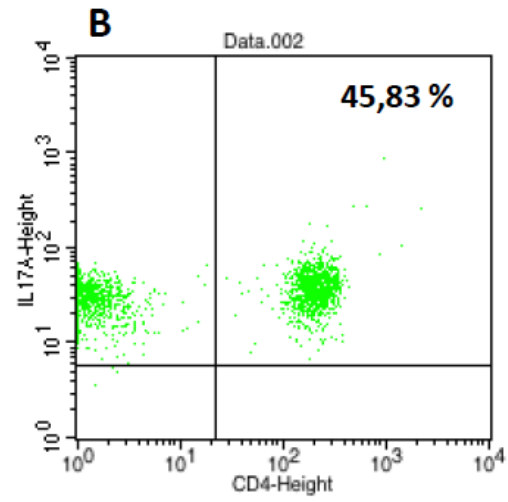

Gambar 2: Prosentase Th 17 antara kelompok kontrol sehat (A) dengan pasien LES (B) Prosentase Th17 (CD4+, IL17+) kelompok pasien LES secara signifikan lebih banyak Hubungan Antara Jumlah Th 17 Dengan dibandingkan kelompok kontrol sehat Kadar Vitamin D Pada Pasien LES Tabel 4. Hubungan antara Th 17 dengan kadar vitamin D

\begin{tabular}{ccccc}
\hline Karakteristik & $\mathbf{N}$ & Mean \pm SD & Korelasi Pearson (r) & p-value \\
\hline IL17 & 15 & $4,406 \pm 0,97$ & $-0,33$ & 0,22
\end{tabular}

Dari tabel diatas diketahui bahwa tidak ada hubungan antara sel Th 17 dengan kadar vitamin $\mathrm{D}(\mathrm{p}=0,22)$

\section{PEMBAHASAN}

Kadar Vitamin D antara Kelompok Pasien LES dan Kontrol Sehat

Pada penelitian ini dapat dibuktikan bahwa secara signifikan terdapat perbedaan kadar vitamin $\mathrm{D}$ antara kelompok pasien LES dan kontrol ( $p$-value $=0.00)$. Beberapa penelitian sebelumnya menunjukan hasil yang sama, bahwa sebagian besar pasien LES memiliki kadar vitamin D yang rendah. Penelitian Kim Hyoun-Ah, et al (2010), yang menunjukkan kadar $25(\mathrm{OH}) \mathrm{D}$ pasien LES di Korea secara signifikan lebih rendah dibandingkan kontrol normal dan resiko insufisiensi meningkat 4.6 kali pada pasien LES. Wozniacka et al (2010), menemukan konsentrasi serum 25(OH)Dpasien LES selama musim panas secara signifikan menurun jika dibandingkan dengan kelompok kontrol. Studi cohort perempuan dengan LES yang dilakukan oleh Toloza et al (2010) menunjukan adanya insufisiensi pada sebagian besar perempuan dengan LES, dengan prevalensi kadar 25(OH)D sub optimal, $66.7 \%$ dan defisiensi, $17.9 \%$. Beberapa studi telah melaporkan, adanya hubungan antara LES dengan defisiensi vitamin $\mathrm{D}$, akan tetapi bagaimana mekanisme vitamin $\mathrm{D}$ dapat meningkatkan resiko LES belum diketahui (Bonakdar et al., 2011).

Bagaimana Kadar vitamin D yang rendah merupakan sebab ataukah sebagai akibat dari LES, belum dapat disimpulkan. Beberapa alasan mengapa hipovitamin D dapat menjadi sebab dari LES adalah terdapatnya bukti-bukti bahwa vitamin D memiliki peran dalam regulasi sistem imun yang dapat mencegah autoimunitas. 
1. Reseptor vitamin D (VDR) yang diekspresikan diberbagai sel sistem imun, diantaranya sel monosit, makrofag, sel limfosit $\mathrm{T}$ dan sel $\mathrm{B}$ yang teraktivasi (Bikle., 2009).

2. $1,25(\mathrm{OH})_{2} \mathrm{D} 3$ dapat meregulasi aktivitas sel $\mathrm{T}$ baik secara langsung maupun tidak langsung melalui modulasi dari sel dendritik sebagai APC (Toubi and Shoenfeld., 2010)

3. Saat stimulasi sel monosit berdiferensiasi sel dendritik imatur (iDC), adanya vitamin $1,25(\mathrm{OH})_{2} \mathrm{D} 3$ memiliki peran meningkatkan kemampuan dalam menangkap dan mengikat antigen yang menginisisasi respon imun (Baeke et al., 2010).

4. Defisiensi vitamin D mengarahkan respon imun menuju hilangnya toleransi dan penambahan vitamin D in vitro akan mengembalikan karakteristik imun abnormal pasien LES (Cutolo., 2009).

Bila kadar vitamin D rendah, maka akan terjadi kekacauan dalam sistem imun berupa hiperaktivitas sel dendritik, hiperaktivitas sel-sel efektor baik sel $\mathrm{T}$ maupun sel $\mathrm{B}$, berkurangnya kemampuan supresi sel Treg, serta meningkatnya sitokin proinflamasi. Rendahnya kadar vitamin D pasien LES kemungkinan disebabkan oleh fotosensitifitas pasien LES karena menghindari sinar matahari, sehingga sintesis vitamin D-nya menjadi terganggu, selain itu faktor predisposisi hipovitamin D LES disebabkan karena penggunaan sun protector. obat kortikosteroid, gangguan ginjal (Cutolo., 2009).

\section{Ekspresi Sel Th 17}

IL-17 adalah sitokin proinflamasi yang meningkatkan $\mathrm{T}$ sel priming dan menstimulasi sel epitel, endothelial, dan fibroblast memproduksi mediator multiple proinflamasi seperti: IL-1, IL-6, TNF $\alpha$ dan beberapa chemokin (Jianxin, 2009). IL 17 mampu menginduksi chemokin seperti IL-8, monocyte chemoattractant protein -1 (MCP-1) dan growth related onkogen protein- $\alpha$ (Cripsin and Tsokos, 2010). Peningkatan serum IL-17 dilaporkan terjadi pada pasien LES. IL-17, IL-23 dan Th17 signifikan terjadi peningkatan jika dibandingkan dengan kontrol normal. IL17 dapat menginduksi produksi autoantibodi yang berlebih dan over-ekspresi dari IL-6 dari PBMC (peripheral blood mononuclear cells) dari pasien lupus nefritis. Dan saat ini konsentrasi IL-17 mempunyai hubungan positif dengan LES desease activity index (LESDAI) score. Sehingga penemuan IL-17 dan sel Th 17 adalah penting pada pasien LES ( Jianxin, 2009)

IL-17 diproduksi oleh beberapa tipe sel yang meliputi $\mathrm{T}$ sel subset $\left(\mathrm{CD} 4^{+}, \mathrm{CD}^{+}\right.$ dan TCR- $\alpha \beta^{+}$CD4- CD8 $\left.{ }^{-}, \mathrm{TCR}-\gamma \delta\right)$, sel natural kiler dan neutrofil. IL-17 berperan penting dalam respon imun melawan bakteri dan fungi. IL-17 juga mengaktifasi sel $\mathrm{T}$ dan berinfiltrasi ke jaringan dengan melalui intarseluler adhesion molekul-1 (ICAM-1) dan meningkatkan respon imun dengan menginduksi produksi IL-6, prostalglandin E2, granulocyte-macrophage colony stimulating factor (Cripsin and Tsokos, 2010)

Telah dilaporkan dalam suatu penelitian bahwa terapi dengan agonis VDR menghambat sel $\mathrm{T}$ dalam produksi IL-17 yaitu suatu sitokin proinflamasi yang diproduksi oleh sel T patogenik (Th 17) dari beberapa model dari organ spesifik pada autoimun dalam otak, jantung, sinovial dan intestinum. Menariknya lagi produksi IL-17 oleh IL-23, IL-12 yang terdiri dari rantai p19 dan p40 secara kuat dihambat oleh VDR. Saat ini terapi $1,25(\mathrm{OH})_{2} \mathrm{D}_{3}$ secara signifikan dapat menghambat progenitor pertumbuhan lymphoid normal baik sel $\mathrm{T}$ maupun sel $\mathrm{B}$ tanpa memberikan efek sitotoksik. Jadi mekanisme vitamin D dapat memodulasi respon autoimun adalah sebagai berikut DCs adalah target utama untuk aktifitas imunomodulator oleh $1,25(\mathrm{OH})_{2} \mathrm{D}_{3}$ dengan menghambat deferensiasi dan maturasi DC 
selanjutnya menghambat prekusor monosit menjadi imatur DCs. $1,25(\mathrm{OH})_{2} \mathrm{D}_{3}$ Th 1 dan Th 17 memberikan respon sitokin, menginduksi sel Treg, induksi IL-4 (Th 2) dan fungsi NKT-sel. Deferensiasi dan maturasi sel B juga dihambat.

\section{Hubungan antara Status Vitamin D dengan Ekpresi Sel Th 17}

Pada penelitian ini didapatkan hasil, bahwa tidak ada hubungan antara kadar vitamin $\mathrm{D}$ dengan Th 17, akan tetapi terdapat perbedaan jumlah prosentase IL-17 pada kelompok hipovitamin D dan kelompok pasien yang normovitamin $\mathrm{D}$, dimana pada kelompok yang hipovitamin $\mathrm{D}$ ditemukan jumlah prosentase IL-17 yang lebih tinggi daripada yang kelompok normovitamin D dan kontrol.

Sel Th 17 adalah Subset set $\mathrm{T}$ yang memproduksi IL-17 yang memperantarai inflamasi jaringan dengan menginduksi berbagai sitokin proinflamasi dan kemokin. Dalam jumlah dan fungsinya yang normal berperan sebagai imunitas bakteri pathogen. Tetapi jumlah yang berlebih berhubungan dengan penyakit auto imun (Harington et al.,2005).

Produksi IL-17 tinggi pada peripheral blood pasien dengan LES (Wong et al., 2008) dan dikatakan berhubungan dengan aktifitas penyakit LES (Doreau et al., 2009). Hal ini sesuai dengan hasil penelitian, pada pasien hipovitamin D menunjukan prosentase IL 17 yang lebih banyak dibandingkan dengan pasien LES normovitamin D maupun kelompok kontrol. Peningkatan IL-17 kemungkinan berkontribusi pada rekrutmen dan aktivasi sel imun neutrofil dan sel $\mathrm{T}$ pada organ target sehingga menimbulkan respon imun. Peningkatan dari IL-17 kemungkinan juga akan berakibat pada stimulasi sel B sehingga dikatakan patologi dari LES melalui IL-17 (Cripsin and Tsokos, 2010).

\section{KESIMPULAN}

Dapat disimpulkan bahwa 1,25(OH)2D3 mempengaruhi tahapan siklus hidup sel. Efek ini dapat berkontribusi secara substansial untuk mengurangi aktivasi sel $\mathrm{T}$ dalam menginduksi perkembangan sel Th 17 . Oleh Karenanya mungkin pemberian terapi vitamin D (analog 1,25(OH)2D3) dapat memodulasi dalam pengobatan penyakit autoimun, khususnya pasien LES.

\section{DAFTAR PUSTAKA}

Adams, J.S., and M. Hewison. 2008. Unexpected actions of vitamin D: new perspectives on the regulation of innate and adaptive immunity. Nat. Clin. Pract. Endocrinol. Metab. 4(2): $80-90$

Anolik, J.H. 2007. B cell biology and dysfunction in SLE. Bulletin of the NYU hospital for joint diseases. 65(3): 182-6.

Baeke, F., Takiishi, T., Hannelie, K., Conny, G., Chantal, M. 2010. Vitamin D: modulator of the immune system. Cuurent Opinion in Pharmacology. 10:482-496.

Bikle, D. 2009. Nonclassic actions of vitamin D.J. Clin. Endocrinol. Metab. 94(1): 2634.

Bonakdar, L., F. Jahanshahifar, A., Gholamrezaei. 2011. Vitamin D deficiency and its association with disease activity in new cases of systemic lupus erythematosus. LUPUS. 20: 1155-1160

Crispin, J.S., and J.A. Varela. 2007. The role myeloid dendritic cells play in the pathogenesis of systemic lupus erythematosus. Autoimmunity reviews. 6(7): 450-456.

Cutolo, M. 2009. Vitamin D and autoimmune rheumatic diseases. Rheumatology. 48: 210-212.

Doreau A., Belot A., Bastid J. (2009). Interleukin 17 acts in synergy with B cell-activating factor to influence B cell 
biologi and the pathophisiology of systemic lupus erythematosus. Nature Immunology, 10:7. 778-785

Dusso, A.D., Brown, A.J., Slatopolsky, E. 2005. Vitamin D. Am. J. Physiol. Renal. Physiol. 289: 8-28.

Ghoreishi, M., Bach, P., Obst, J., Komba, M., Fleet, J.C., Dutz, J.P. 2009. Expansion of antigen-specific regulatory $\mathrm{T}$ Cells with the topical vitamin $\mathrm{D}$ analog calcipotriol. J. Immunol. 182: 6071-6078.

Irastorza, G.R., Egurbide, M.V., Olivares, N., Berritxoa, A.M., Aguirre, C. 2008. Vitamin D deficiency in systemic lupus erythematosus: prevalence, predictors and clinical consequences. Rheumatology. 47: 920-923.

Jianxin LU., Bonnie, K.W., Cheukchun, S. (2009). Up date on the role $\mathrm{T}$ cell subset in the pathogenesis of systemic Lupus Erythematous. Journal of Chinese Clinical Medicine. 4(7): 400-409.

Kalim, H. 2000. HLA klas II dan kerentanan genetik terhadap LES di Indonesia. Acta Med Ind. 32: 11-15.

Kim, Hyoun-Ah. K. Bo-Ram., J. Ja-Young., K. Keon-Young., S.Chang-Hee. 2010. The 9th International Congress on SLE June 2427 2010, Vancouver, Canada. LUPUS. 19:1.

Sayed, M.E., Nofal, E., Mokadem, S.A., Makhzangy, I.A., Gaballah, H., Akl, H. 2008. Correlative study of serum Th1/Th2 cytokines level in patients with systemic lupus erythematosus with SLEDAI. Egyp. Dermatol. Online. J. 4(1): 1-15.

Shakra, M.A. 2008. Do improved survival rates of patients with systemic lupus erythematosus reflect a global trend?. The Journal of Rheumatology. 35: 19061908.

Szodaray, P., Nakken, B., Gaal, J., Jonsson, R., Szegedi, A., Zold, E., Szegedi, G., Brun, J.G., Gesztelyi, R., Zeher, M., Bodolay, E. 2008. The complex role of vitamin D in autoimmune diseases. Skandinavian Journal of Immunology. 68 : 261-269.

Toloza, S., D.E.C., Cole. D.D., Gladman ., M.B., Urowitz. 2010. Vitamin D insufficiency in a large female SLE cohort. LUPUS . 19: 13-19

Toubi, E., and Y. Shoenfeld. 2010. The role of vitamin $\mathrm{D}$ in regulating immune responses. IMAJ. 12: 174-175.

Wong C.K., Lit L.S., Tam E.K and Lam C.W.K . (2008). Hyperproduction of IL-23 and IL-17 in Patienst with systemic lupus erythematosus :implications for Th 17 - mediated inflammation in auto-immunity, Clinikal Immunologi, Vol.127,no.3.pp,389-393

Wozniacka, Anna McCauliffe, Daniel P. Bogaczewicz, Jaroslaw Lukaszkiewicz, Jacek Kaleta, Beata SysaJedrzejowska, Anna. 2010. The relationships between serum vitamin D levels, vitamin D receptor polymorphism, anti-vitamin D autoantibodies, IL-17 and IL-23 levels, and clinical parameters in SLE patients. The 9th International Congress on SLE June 24-27- LUPUS. 19: 1. 